\title{
essar REPORTAGE: \\ methodology of literary journalism
}

Copyright (๑) 2018 SBPjor / Associação Brasileira de Pesquisadores em Jornalismo
RAÚL HERNANDO OSORIO VARGAS

Universidad de Antioquia - Antioquia, Colombia

ORCID: 0000-0002-8286-7649

DOI: 10.25200/BJR.v14n3.2018.1124

\begin{abstract}
I sustain in my book El reportaje como metodologia del periodismo: una polifonia de saberes (Reportage as the methodology of journalism: polyphony of knowledge), (Osorio, 2017), that journalism leads, guides, interprets, explains, teaches and above all tries deeply to understand the world and its running; thus its essence is freedom of thought, expression and social dialogue or conversation to set in place and to enhance consensus and democratic participation. In this process, journalism shows and enlightens ways (methods) through reportage, which has been very much so studied as a journalist genre around the world; countless books and articles have been published about it and several universities have granted PhD titles for theses written about it. The North American and European bibliography on it is abundant - which has been taken in consideration at this research and widely known; but little is known of what has been done in our continent. Therefore, in this book I put in perspective two major examples: Brazil and Colombia. Nevertheless, I must emphasize that when this subject is addressed, it is done so through the lens of journalistic genres, but not under the dimension of the methodology of journalism, which has been away from the eyes of theoreticians, scholars and researchers. In this sense, my book is an epistemological turn, as it is innovative and pioneer for contributing with another vision, which studies, analyses and proposes reportage as the methodology of journalism, by presenting some findings and by opening new theoretical perspectives in literary journalism. Key words: Journalism. Reportage. Methodology. Interview. Method.
\end{abstract}

\section{REPORTAGEM: metodologia do jornalismo literário}

RESUMO - No meu livro A reportagem como como metodologia do jornalismo. Uma polifonia de saberes (Osorio, 2017), sustento que o jornalismo orienta, guia, interpreta, explica, ensina e acima de tudo tenta compreender em profundidade o mundo e suas ações; por isso sua essência é a liberdade de pensamento, de expressão e de diálogo social ou conversação para pôr em comum e fortalecer o consenso e a participação democrática. Nesse processo, o jornalismo mostra e ilumina caminhos (métodos) através da reportagem, que em todo o mundo tem sido amplamente estudada como gênero jornalístico; e em torno dela temse publicado numerosos livros e artigos, e em diversas universidades foram concedidos títulos de doutorado por teses feitas sobre o tema. A bibliografia europeia e americana que tratam o assunto é abundante -e que tive em conta para esta pesquisa-, é de conhecimento geral; mas o que é produzido em nosso próprio continente é desconhecido. Por isso, nesse 
livro, concentrei-me em dois exemplos importantes: o que foi feito no Brasil e na Colômbia. No entanto, devo reiterar que, quando o tema proposto é abordado, se faz desde a ótica dos gêneros jornalísticos, mas não sob a dimensão da metodologia do jornalismo, que tem estado oculta as miradas dos estudiosos, teóricos e acadêmicos. Neste sentido, o meu livro constitui um giro epistemológico, pois é inovador e pioneiro ao contribuir com outra visão, que estuda, analisa e propõe a reportagem como metodologia do jornalismo, ao mostrar algumas descobertas e abrir novas perspectivas sobre as teorias do jornalismo literário. Palavras chave: Jornalismo. Reportagem. Metodologia. Entrevista. Método.

\section{REPORTAJE: metodología del periodismo literario}

RESUMEN - En mi libro El reportaje como metodología del periodismo. Una polifonía de saberes (Osorio, 2017), sostengo que el periodismo orienta, guía, interpreta, explica, enseña y sobre todo intenta comprender en profundidad el mundo y su accionar; por eso su esencia es la libertad de pensamiento, de expresión y de diálogo social o conversación para poner en común y fortalecer el consenso y la participación democrática. En ese proceso, el periodismo muestra e ilumina caminos (métodos) a través del reportaje, que en todo el mundo ha sido muy estudiado como género periodístico; en torno a él se han publicado numerosos libros y artículos, y en diversas universidades se han otorgado títulos de doctorado por tesis realizadas sobre el tema. La bibliografía europea y estadounidense al respecto, que es abundante $-y$ que he tenido en cuenta para esta investigación-, es de conocimiento general; pero se desconoce lo producido en nuestro propio continente. Por eso en ese libro me centré en dos ejemplos importantes: lo hecho en Brasil y en Colombia. Sin embargo, debo reiterar que cuando se aborda el tema propuesto, se hace desde la óptica de los géneros periodísticos pero no bajo la dimensión de la metodología del periodismo, que ha estado oculta a las miradas de estudiosos, teóricos y académicos. En este sentido, mi libro constituye un giro epistemológico, pues es novedoso y pionero al contribuir con otra visión, que estudia, analiza y propone el reportaje como metodología del periodismo, al mostrar algunos hallazgos y al abrir nuevas perspectivas sobre las teorías del periodismo literario. Palabras clave: Periodismo. Reportaje. Metodología. Entrevista. Método.

\section{Introduction}

This paper works with the hipothesis according to which reportage is the key engine of an epistemology of literary journalism. Here, the notion of reportage is built from its etimology, its early years as a narrative form and its consolidation through the immediate experience of the reporter that became a historian and a narrator of multiple times. Reportage is the methodology of journalism, and the search for human comprehension is the energy source that keeps it alive, its means for producing meaning and knowledge. The transformations of reportage in several periods show the manifold tendences that are combined in literary journalism, which generates meaning as it faces with severity and consistency of investigation the many problems of the world. When they analyse the phenomena of the lived, experienced and shared reality, literary journalists amalgamize reportage, essay, image and sound as in a kind of film editing that conceives lore (epistemology) 
and transcendent analysis of the contemporary sociopolitical realities and cultural discourses. Reportage is a methodology that was born with press journalism but has evolved independently since it cannot exist without continuously interacting and communicating with others, with the distinct voices of society. Reporting is still supported in online journalism, in a both global and local scope, by using the ICT in favour of a professional activity of high quality, in its hipertextual, multimedia and interactive narratives.

Reportage as a methodology is present in 1.0 Journalism, in which contents are transported from the print outlet to the digital website; in the hybrid 2.0 Journalism, in which there is native hipertextual, interactive and multimedia narrative content; in 3.0 journalism, in which receivers intervene in the message and the prosumer (producer and consumer) emerges along with citizen journalism, blogs, original content and a form of interactivity that brings more participation - in this model there is also semantic web, which main service is interconnecting many kinds of knowledge. Finally, reportage as a methodology is present in the movement towards 4.0 Journalism, which is associated with the notion of webOS, a platform that interacts with the users via the web browser and does not depend on the operational system. Furthermore, it is present in virtual reality, resulting in immersive journalism. Nonny de la Peña, a pioneer in this kind of reporting that submerge people in the slums of Los Angeles or in the hardships of life in contemporary Aleppo, had her works backed by Google, Associated Press and Tribeca Film Institue, and was awarded in the Sundance Film Festival. De la Peña, in many of her videos uploaded to Youtube, states that the advancement of virtual reality is unstoppable and will be essential to journalism. She says journalists will quickly realize that virtual reality has a unique capacity for situating spectators in the scene of an event instead of looking at it from the outside, and this powerful form seduces them through their feelings. She explains that RV adapts itself in special to a king of story in which significative events take place in a specific scenery, and that people will quickly learn to say: "this should be told in RV". However, she warns us that we should be careful when enacting such scenes and should stick to major journalistic practices ${ }^{2}$. This means that the methodology of reportage is a systematic cross-referencing between the evolution of literary journalism through the many times it was practiced and its transdisciplinarity, its ethics and its dialogue with different methods and lores of Humanities, Social Sciences and Literature. 
Literature is a lifeform because life, just like Literature, is dissonant, ambiguous and ambivalent. In Literature there are no clear and distinct ideas, there are no principles that tell us how one must read, the correct way of reading. In Literature, just like in life, there are no unequivocal sign that show us the correct interpretation (Mèlich, 2015, p. 13-14).

The history of literary journalism is full of contacts and borrowings. Thus, this paper has a wide and complex agenda that comprehends the process of journalistic production and its construction in language through different forms, structures and times; qualitative investigation, methodology and epistemology; the history of journalists and of journalism. My focus is the multiple relations of literary journalism with culture, memory social theories, discourse and technologies, fields that were approached and analyzed in Iberoamerica and throughout the world.

Since Tobias Peucer's first presentation of a PhD Dissertation in Journalism in 1690, in Germany, international literary journalism studies have experienced important developments as a form of knowledge, professional practice, social rethorics and narrative in journalism theories, narrative theories and literature theories. In literary journalism's journey through tradition and modernity, the methodology of reportage is indissolubly attached to a perception of human events.

The epistemological investigation of reportage may be summarized in an action, in a way of acting: the act of reporting. However, one must look for the roots and developments of that creative proccess since the origins of the word. In order to do that, we outline what is reportage, what is the act of reporting, and how journalists have acted as narrators and hommes de lettres. Also, in order to propose a philosophy of reportage, we resort to the borrowings it made from other fields of human knowledge. Here the indispensable value of the senses in essential. By constrasting the texts of pioneers of reportage with the later tradition and other voices of Latin America we then find how reporting has consolidated its methodology. In the light of this philosophy of authorial reportage, we hae the possibility of accessing the creative process, the new forms of reporting, the audacity, the renovation and the ethicalaesthetic-poetic function of reportage, in which texts it is possible to see, read, observe, interrogate and theorize, in order to reach the conclusion that reportage is the methodology of literary journalism.

This theoretical proposition demands interview as the fundamental tool of literary journalism. Reportage is always done 
based on the flagrant statements that surface in a dialogical system of orality and writing and investigation. Opening huge posibilities in transcultural journalism, we offer up a question: what is the proccess through which a reporter walks in the path of constructing knowledge? The old layer of literary journalists, just lile the new generations, must walk through the paths of memory in synchony with the world, focusing on our local realities but not forgetting the universal ones, using without any prejudice open methods that allow them to reconstruct and recreat the history of everyday life. From this everyday life the language of narrators emerge. Is there an ideal reportage? Or are the many propositions of journalists and journalisms that assume new configurations woven by the complex world of multiple voices in dialogue?

In order to study reportage, one must have in mind the trends of the practice. It is very important to review the dialogue between the past and those who transform the traditional ways of reporting, despite not being acknowledged by mass media for being too young. Albeit reportage is a creative genre, open to the realities it investigates, it is not fiction, and has been converted into the methodology of past, present and future journalism, writing even small new chapters in contemporary history. However, in order to evolve, it has the need to find new methods, new paths and ways of looking at the world.

The investigation we have made considers the existence of social reality as the basis to contextualize the narrative in reportage. It is not dead: on the contrary, it is only being born. The Humane Being, in its fantastic journey, is narrating its traces, its lost footprints that were recovered by new generations who are surprised by the trajectories of their ancestors. The old, the new, tradition, rebellion, turmoil and tranquility are in conversation in order to transform life into a narrative of voices and achievements available to the generations to come. However, how is such a narrative process developed, how do reporters report? Through a critical revision of the worldview that aleays urges us to learn with the generosity, the empathy and the comprehension of the Humane Being, since the insular notion of "human being" is dying in the present days, and in the age of open, multidimensional and complex theory the Humane Being is revived, since humane qualities and humankind are bigger than modernity.

The humanization of the relation between subjects, through the method of interview, contemporaneity in its polyphony and reportage 
as the place of collective memory that allows for the reporter to intervene in society. I must stress that, when I speak of humanization, I make a reference to the process through which typical features of the Humane Being are acquired. There is a difference that is fundamental to journalism: seeing something means a visual activity, a swift action, while looking at something is a slow, long action that is conscious of some degree of analysis. The possibilities of that dimension and of life constitute the genesis and the development of this proposal. The paths we have walked show the open routes for narrating the human events and achievements of our time and for building a transcultural, convergent, transmedia, contemporary literary journalism.

Such a method must have an ethical definition (the humanization of the contemporary discourse); the construction of mediator reports (orality) illuminated by the aesthetic investigation (transmedia-convergent-literary-reportage), turning literary journalism into an activity that generates forms of knowledge, in which center stands the Humane Being.

\section{Methodology}

As widely known, methodology is the science of methods, or the set of methods used in a research, composed by two main kinds: qualitative and quantitative, which on their turn comprehend their own sets of methods. In tradition, there are three main groups: historical, interpretative-descriptive and experimental methods. On the other hand, there are groups of methods: in Humanities, in Social Sciences, in Arts.

Through the means of reporting ${ }^{3}$ the methodology of journalism (reportage) has historically contributed to the development of investigation with its similarities and differences, appropriations and contributions to the other forms of research in Humanities and Social Sciences, in a process of dialogue, interdisciplinarity and transdisciplinarity. However, in order to reach this point, we must recall its origin and the central activity in journalistic eorl.

The Latin verb reportatre means to transmit, to discouver, to announce, to bring news. $R e$ is a prefix that designates a movement backwards - here Is the past. Portare means to carry something - here is the present walking towards the future. Repor means the act of reloading, reconstituting. Thus, reporting means (re)turn round oneself. The journalist porte la parole (carries the word) in order to bring us back. 
À portée de la voix (within reach of the voice) an ancient word, reportare, becomes a new expression: news report in English, reportage in English, Italian and French, reportaje in Spanish, reportagem in Portuguese. It carries letters, voice and also life: this neologism implies hermeneutics, because it is an art of interpretation and of comprehension; not of sacred texts anymore, but of life itself. In orderto interpretate, first we need to understsnd and for this we need to submerge in the Humane Being. The practice of reportage shelters a passion: the challenge of knowing, discovering and reporting not only with the brain, but also with the heart, with all senses, and in multiple times and spaces. This is another method for living again what has already happened.

The report (narrative and description) was born with the human being... Sagas, legends, traditions, stories, tales are the quintessence of peoples and compose the history of the world and its many kinds of knowledge. The words are with us since always: as moans, screams, sonority and voice. All of those, first in oral form and later in written form, tell the story of travel, accumulate and construct the memory of women and men who do not conform with losing their lives, trying to convert what is temporary into eternal.

The journalism-related words "reporter" and "gazeteer" originate from the rapportisti and gazzettani of Venice. Gazzeta was a small venetian coin worth a sheet of handwritten news that were sold in shops of that mercantile republic. The menanti, also known as novellanti, rapportisti or gazzetanti, were professionals from early Renaissance Italy who offered correspondence services for noblemen and merchants. In France the men who worte those news sheets were called nouvellistes or gazettiers (Balle, 1991, p. 74).

\footnotetext{
The year 1440 marks the beginning of what Marshall McLuhan calls the "Galaxy of Gutenberg". Thnaks to the invention of the moveable-types press, the sheets written by rapportisti have expanded their reach and influence. The first print papers had diverse functions: some were limited to offer news in order to make money for the printers, while others aimed to publicize new ideas and propose subjects for reflecting upon sociopolitical reality (Gutiérrez, 2014, p. 1).
}

Thus, we must go deep into the roots of reportage in order to demonstrate the elements that compose this methodology of journalism, and our first approximation focuses on its etimology:

$R e$-: from the Latin prefix re- that means rebuild, "behind something", reflow, denotes intensification. Reload. 
Port: from the Latin portāre. Having something with oneself, or on oneself. To carry, to drive something from a place to another. Pronominal verb. To act or proceed in a determined manner.

Report: from the Latin reportāre. Transitive verb: to reach, to achieve, to obtain, to bring or to take. To provide, to transmit, to communicate, to bring news.

-age: from the French-age and the Occitan and Catalan-atge, and both from the Latin -atǐcus. A suffix which forms substantives that mean an action.

This means reportage is the action or the succession of events and achievements that constitue its argument, its argumentation. From the ancient suffix-adgo, and the Latin suffix-atícus, which means condition or state. Reportatǐcus or reportadgo, finally reportage... is not only a journalistic genre, but the very methodology of journalism. Journalism is a way of acting and practicing. It is what reporters do in order to develop the process of reporting (news, note, narrative): the journalist who interviews someone ${ }^{4}$, the journalist who looks for news and publicize them through several media. Reportage is a methodology composed by several methods and techniques - among the most commumon are observation, participante observation and interview in the process of experience. Reporting has as its main axis the first, since it is the medium par excellence to aprehend social aspects that manifest in experience and to point the proceedings to collect registers and situations lived in the contexts that are studied. Through his or her experience the reporter observes reality in order to participate, and also participates in order to observe.

The rationalist paradigm relegates observation to a prescientific level, a huge mistake, since observation is a process consisting of distinct modalities, attitudes and levels of depth in human knowledge. Observations allow journalists to study communities from the inside, and this first contact provides a first approximation to reality by attempting to reach an understanding of what happens there, attempting to understand the point of view of the people: to know how they read reality. There are certainly many ways of observing, but the one that literary journalism traditionally uses features a flexible an open look at the world. That is the look of the stroller or flâneur, as called by the French. 


\section{The infinite search...}

The spiral of visions we get from a journey through cities is fundamental to know the past and to enter a deep understanding with more complex images from the urban space - scenes made to dive in the scenery and human conditions-, the best school for journalists who look for traces of the ancient and the paths of the present, methods that flow under the ritual of the expectative of the time that will come through the rescue of a memory, scenes that come from the street, from the acute senses $^{5}$ of the Humane Being. From the turbulent reality that becomes another, reporters build their expression, their complex manifestations assume heterogeneity without renouncing to universal features that were always present in their way of being, marking their culture in uncountable variations in order to become a priviledged vehicle of communication and expression of feelings.

The narrative reporters who write about cities have built their methodology through their walks. A good definition of method is a path - "traveler, there is no path, the path is made by walking": this is what journalists do with their inventiveness. This means meeting the crossings of Latin Americans; of farmers who moved to cities.

In my book El reportaje como metodología del periodismo [Reportage as the method of journalism], there is a reading - which is not complete nor exhaustive - of reportage about cities. There I have looked for a philosophy of literary journalism and a theory of reportage as a methodology. In the metaphors, in the ruptures of those narratives, we finds ways of looking at the world of the Humane Being. There is the cosmovision, the varied panorama of the multiplicity of expressions, the diverse speeches of deep popular roots. A way of expressing the urban feeling that does not dodges social, cultural and political reality. Here the voices are product and expression of the city, which subjects and motives range from love to social injustice. The cultural luggage acquired in the corners of the streets show us the rural survivors in the space of the city, where we find the beginning of the management of the poliphony of voices that, albeit different and diverse, sound together to turn observations and appreciations into important details that aggregate to the big themes that determine the lights and shadows of our $21 \mathrm{dt}$ Century 
cosmovision. Culture stimulates new studies, new readings, new proposals. The values transmitted by reportage about cities are the reivindication of culture generated by the inhabitants in their multiple amalgam. Words point us the horizon: the poor, people with scarce resources, indians, urban people, simple people; a horizon full of metaphoric logic, image, love, sense of community, expressive and possible dialogue.

Reportages always hide something unknown waiting to be discovered in the millennial search it collects past human times that are still alive in our memories as cultures in dialogue with our own, harassed by the need to tell its trajectory to know (and taste) the silent laws that move us and feel the threads of times. There we find the struggle for life, the struggle of citizens looking their universal meaning in the village. The past is in everything. Consecrated roots in the everyday life, in the search for manners, styles in the secrets of the light of memory. Poetry and precision while building spaces, details that illuminate places with the intention of understanding the space where one lives. The human being in its geography, as defined by Milton Santos: Geography is the history of space, just like History is the geography of time

By exploring what the person knows, since everybody has a chest - albeit there are diverse and complex kinds of memory - we obtain the diversity of voices and a tone that has a sacred quality. Thus, this heterogenous sign is inversed, reversed, to reach our anthropofagy: it its eternally reportage. The myth of eternal return, the narrative that always return to furrow through the paths of coexistence between us and the world, accompanying the different steps of human evolution so that a new group of narrators emerge with full strength, reinterpreting and understanding, each in their own manner, the journey of the hope of the Humane Being.

Reportage is a being in communication. Conversation is reportage of words, of gestures, of images and of the diverse ways of communicating. Each in their own form, their own way, nurture our human dialogues. And through the narrative we find the image of those who are in need, in a city afflicted by unemployment and violemnce, but also in a city with its spaces of richness, development and welfare. And there is the journalist to establish a dialogue with the city as a human totality, with its diverse prisms, its multiple speeches. 
By describing places and scenes in time methodologyreportage is characterized as a kind of magical realism. Reality is magical by itself. There is no novelty in saying this, for the Latin American novelists have demonstrated this prism of human life with an ample mark of truth and historical reconstitution, and at the same time have started with a fine lucid observation in order to documentate and contextualize the work of the mediator. The heroes are the true characters of flesh and blood, beings with a deep life, with a cosmovision of the world. City reporting features freedom of angle, inverview and investigation. Speech is the tuning for the journalist to recreate it since his or her point of view; it is his or her sensibility what provides the rhythm and the tone. It is like a dance in the age of time.

Reportages about cities are an open space to each person that contains a universe full of sensibility in which a real dialogue is established so that we do not get lost in the jungle of globalized information, where the Humane Being ends up being a number, a screw, a nut (although the big city is the place and the moment in which the subjects are confronted with the contemporary world, where the material life, the intellect and the spirit present a diversity of forms of change and resistance). City, ways of life of the urban culture, feverish time of the crowds, loneliness and crisis. City, a privileged place for participant observation - a method of knowing a different world born with Sociology in the late 19th and early 20th century, and which navigates with empathy and astonishment through the urban ways of life and the entanglements of current society, in which the psychological profile of the subjects suggests the theme of the day, a meeting place for the diverse memories and oralities of the metropolis. Reportage reaches another sensibility, because the city is its people (Osorio, 2017, p. 94-97) in a methodology to not only reflect on how the act of reporting is done, but also to enter into the practice of doing it. Since "life is the story of an unconsciousness that became real. Everything that reposes in it aspires to become an event" (Jung, 1986, p. 13).

The Hero's Journey ... in our case, the journey of the antiheroes of the city, and in which the dialogue between writing and orality is also present (Osorio, 2017, p.98). As Cremilda Medina says (1995, p.8), "more than the talent of some, being able to narrate is a vital necessity ..." Although in the beginning it was silence. Then came the family composed of thousands of human beings. A certain 
group of families formed an association, which the Greek language called a fratría ${ }^{6}$ and the Latin language called a curia ${ }^{7}$. It was a small society modeled precisely after the family. The association kept increasing and several curias or fratrías grouped among themselves and formed the tribes. The times passed until the tribes saw the need to associate. On the day that this alliance was celebrated, the ancient city - which was a confederation - was born. Urban space and city were not the same thing. The city was the association of families and tribes. The city was the meeting place, the place of residence, and, above all, the sanctuary of this association. Today they are synonymous with a new human order. The reporter walks to know the construction of this polyphonic fabric, moving and mixing himself or herself in the city spheres. "Living means creating spheres," as Sloterdijk ${ }^{8}$ told us. Frontier cities, gigantic resonance boxes, located on the edge of the colonial, the modern and the postmodern, and scenarios of hybridizations where we stop being inhabitants in order to be passengers of their zones of separation.

The contemporary city and its infinity of possibilities, which beyond the streets is a living organism woven of shared experiences. The city is a livelihood of human adventure, because it is the people who live it and thanks to the seductions of conversation, of the encounter, of the inter-view beyond the times, they can be known and narrated. That is, it is possible to know the city in its complex, contradictory, intermediate and transit realities... human rivers, crowds, laboratories and privileged spaces of human understanding, where the reporter, nomadic viewer, lives and builds the knowledge of passive journalism, inhabitant educator of freedom and opinion, in other words, citizen educator, since urban dynamics prefigure the assumption of other ways of being and being in the world.

\section{The inter-view-encounter}

As a development of the proposal made in my book, I will advance here the importance of the method of the inter-viewencounter in this methodology. The conversation or inter-viewencounter is a fundamental method of the reportage methodology since it allows us to inter-view beyond the surfaces and to understand a phenomenon in depth in order to narrate it. Interview for what? Inter-view, looked, heard and felt as dialogue, encounter, 
deep communion conversation, reportage method that produces knowledge. Polyphonic dialogue that transforms a field interview into an experiment in equality.

Here is the interview: the path of encounter with the other. In the work of the reporter, the interview is the way to look for the human expressions that remain on the threshold of the most intimate part of the culture. We know that both written and transmedia reporting are preceded by speech and that the art of narrating is part of life itself, integrated into social manifestations. The interview that comes out of the everyday life, of the Human Being, weaves the stories that are part of the event in the community. In order to revive the past and fix the present, we have to go through our orality and we must reinstate the old practice of dialogue among humans, in which the various parts come out enriched.

The methodology of reportage depends on interviews with people, research subjects or narrators, who are our collaborators and partners in our project. However, what emerges from these testimonies is the version of achievements, which is why interviews were always on the agenda, in the form or way of capturing life experiences. Listening with refined ears is the path for greater reflection and time, a mastery of the art of listening to the other and living in harmony with him or her. The conversations of reporters with their interviewees show us the ways of communication, i.e., communion. Through these paths, the reporter develops the interview beyond technique, in its dialogical virtues. The Brazilian researcher Cremilda Medina proposes that:

In the daily life of contemporary man there is room for possible dialogue. There are experiences or exceptions to the rule that promote the degree of concretization of the interview in collective communication. Their greater or lesser communication is directly related to the humanization of interactive contact: when, in one of those rare moments, both -interviewee and interviewer- come out "changed" from the encounter, the technique was surpassed by the "intimacy" between the I and the You (Medina, 1995, p.7).

Under this view, interview is the essence of quality journalism and of the method of reportage. Likewise, in the human sciences the interview evokes, and will still evoke, a gigantic critical and methodological work. The interview, evidently, merges into the most doubtful and richest of the sources, the word. She faces the permanent risk of dissimulation or fabulation. 
The closed question constrains an intimidating alternative, imposes a scheme and faces the risk of maximum error, while on the other hand, that of coding, interpretation and exploitation offers maximum guarantees. The open question and the spontaneous response allow (and, above all, for deep analysis) for fabulation, truth sensitivity and a wealth of meanings: albeit this time the maximum risk of error is on the side of the interviewer, of his ability to decipher the interviewee's message, of his ability to establish a comparison, in a nutshell, his ability of transforming a raw human document into scientific data (Morin, 1995, p. 211 ).

The interviewer must possess a rare degree of objectivity and subjective participation. Which means that the reporter must live up to the role of lay confessor of modern life. Here is the reason for the interview, a term that comes from the French word entrevoir, which means "to see each other reciprocally", or even better, to mix, as it has happened for centuries in Our Half-Blood America. Transculturation process. This notion of interview as a method, a path to a meeting, walks hand in hand with experience-action; but an action beyond the physical presences, encompassing the actionon-the-own-experience, or on the experience of others. Experience as a knowledge in movement, experience with the participation of the subject, i.e., the experience of what has been lived, methods of reporting and the field of human sciences: anthropology, philosophy, history, psychology, semiotics, sociology, all concerned with disclosing communication with the other, i.e., with communion in process. Therefore, communication becomes only a "space", a crossroad where the different areas of the social and human sciences meet and merge. There we find the emergence of the human subject in spoken action-experience, a very powerful phenomenon in Latin America, where the majority live in oral culture: expression of their worldview, their feeling, therir thinking, their loving.

Interview is not only an instrument or a tool but a method within a process that addresses the essence of our subjective experience, to arrive at the versions of life and not at an established truth of the facts of the world. Interview, sacred effervescence of communion. But how is interview when seen from the inside? A complex ritual not only on the outside, but also inside the subjectsubject encounter, in the confession of human beings who live extraordinary times of turbulence and emotional urgencies, seeking their way between the sacred and the profane (as the Spanish poet Antonio Machado says: Traveler, there is no path, the path is made by walking), where we the complex way of walking-thinking: 
... is imposed at the outset as an impossibility to simplify; it arises where the complex unit produces its emergencies, where the distinctions and clarities in the identities and causalities are lost, where disorders and uncertainties disturb the phenomena, where the subject-observer surprises his own face in the object of his observation (Morin, 1977, pp. 377-378).

Interview, intelligence in action that transforms the substract of living beings full of experience, who open their hearts and tell their complexities, because history is inside of us, that natural thing that people carry with them, in the first principle of the unity, the self included in the other self. Encounter as a method of knowledge and a network of connections between people, events and the world. The lived experience guides the interview in the dialogue, in the conversation, in the encounter towards otherness, that communion of intimacy in the conscience of each one. The sharing of life experience is the moment in which the revelation of the other can be produced in depth. In the interview method, the participant observer enters the reality of his research subject through empathy. Since we can have the freedom to see the other in the way that art is lived:

\footnotetext{
A novel, a poem, a painting, a musical piece are all individuals, i.e., beings in which the expression of what is expressed can be distinguished, whose meaning is only accessible through direct contact and which radiate its meaning without abandoning its place in time and space. It is in this sense that our body is comparable to the work of art (Merleauponty, 1971, p.162).
}

However, our existence must be put in context. Contexts that are a meeting of specific temporalities and that constitute networks of dialogues. We are subjects who live in different communities with special and porous specialties and temporalities that make up the dimension of human pluralism. In these transculturation ${ }^{9}$ networks we live the experience of observers; but beyond the participant observer we propose the observer of the transcultural experience, from within himself and from the other. In other words, a taste-knowledge of the act of interviewing in reportage as a methodology of literary journalism. Interview, the sacred space in a ritual moment, where the participating subjects relate (to each other) within the territory of communion. Here there are no spectators, only participating actors who through their dialogue make their meeting more and more intense and involving, seeking a fusion in the relationships that each one lives on, in order to experience the climate found in the mutations of the oral history of life, where a written degree of the spoken and a spoken degree of the written are produced: the metaphorical way of the complex affective intonation. 


\section{Reporting what was inter-viewed (in the guise of conclusion)}

In this proposal of reportage as a methodology of literary journalism the inter-view-encounter, the human exchange, the possible dialogue, are a movement and an act that may become a "sacrament", i.e., a communion with the other. It is the history of human beings who live in orality and express for the other the needs that are unique to the lived experiences. It is the methodological workshop of contemporary narrative, paths of the anonymous sages, experimenters of communicative essays called journalism.

The participants of this affective communion, aware of the duties they assume, break the technicality in order to generate a narrative of the subject present in the world, integrated into their experience-action, formed in the intimacy of consciousness, of each of the associates of the encounter, where the existences are like the pages in the book of time. Mediations that live in individuals and in social and cultural relationships, where experiential reportage is born and grows, as a modulation of participatory oralities and a laboratory of the cultural identity of everyday life. The reporter of realities, as a member of society, merges with his subject-object of study. Guiding us through the "labyrinths" of transculturations, where intuition is another of the methods of knowledge in the methodology of reporting. Thus, reporters are bringing together methods, paths, in order to travel in the process of knowing the lives of others. Trans-methods to reach our destination, where each social act has a special meaning that only acquires meaning in the values shared by the individuals of society. In these multiple ways, the investigative reporter will capture the facts that allow him or her to find the subjective motives that drive the behavior of the Humane Being. In the way of comprehension, which implies immersion in intimate experiences, the elements of situations in context they are revived in the mind of the reporter. By these methods, reportage is a social methodology based on ever increasing internalization, in the law written in the heart: we know what is in the outside through what is the inside, but what is inside is also the apprehension of what is outside, depending on the degrees and levels of refinement achieved.

To reach the essence of events, we have to awaken those congenital faculties that allow us to see beyond the appearance of phenomena. In this profound process, reportage expresses and understands everyday life. But where does this road start? Through the core, the hidden and secret place of consciousness, that central, 
highly visible and relatively large organ of the individual: the heart. It is it that reproduces memory through a complex process. For the Uitotos (Colombian Amazon and Peru) heart, chest, memory and thought are the same thing. If the West made the heart the seat of feelings, all traditional civilizations, on the contrary, locate intelligence and intuition in it: perhaps the center of the personality has been dislocated from the intectuality towards affectivity. But did not Pascal say that the great thoughts come from the heart? It can be added that, in traditional cultures, knowledge has a very broad meaning, which does not exclude affective values. Pascal saw the universe as an infinite sphere, whose center is everywhere, and our center is the heart, which together with the senses weaves the rhythm of existence. Recognizing their powers means recreating reality, which is always present, means founding the affectivity that is much desired by the curiosity to see, know, unveil, learn, awake, discover, identify; but especially it means observing, which is contemplation (theoria) and participation of all our senses for the Comprehension of the Humane Being.

\section{NOTES}

1 Aguilera (1992), Borrat (1989) Chillón (1999) y (2014), Gargurevich (1982), Grijelmo (2001), Gutiérrez (1984), Hernando (2000), Martín (1973), Martínez (1983), Martínez (1996), Matute (1997), Melo (2006), Mignolo (1982), Monsiváis (2005) e (2010), Rotker (1992) Vilamor (2000), White (1992), Yanes Mesa (2006).

2 The Future of News? Virtual Reality | Nonny de la Peña | TED Talks: https://www.youtube.com/watch?v=zsLz0mRmEG0\&t=21 $1 \mathrm{~s}$

3 A term that designates the fieldwork of journalists. Through journalistic principles of reporting, we know that the search for information starts with a topic assignment, the first step in news writing, which must also be simultaneously considered as an investigation project, a problem to solve.

4 Later in this paper I will discuss with more depth interview as a method.

5 "The world is a delicious delicacy for the senses. (...) There is no way of understanding the world without first detecting it with the antennae of the senses. (...) Our senses define the frontiers of 
consciousness and, as we are explorers and born investigators of the unknown, we spend a large part of our lives traveling through this turbulent paramenter..." (Ackerman, 1993, p. 13).

6 Among the ancient Greeks, fratria was the subdivison of a tribe that had its own rituals and sacrifices.

7 One of the divisions of the ancient Roman people. It was constituted by the court, the familiy and the king's retinue.

8 Peter Sloterdijk is a German philosopher and scholar from the Karlsruhe School of Arts and Design. His Spheres trilogy begins with an invocation to the senses, sensations and the understanding of the surrounding environment.

9 "Every cultural exchange or, as we shall say from now on, every transculturation, is a process in which something is always given in exchange for something that is received; a "toma y daca", as the Spanish say. It is a process in which both parts of the equation are modified in the end. A process in which a new, composed and complex reality emerges; a reality that is not a mechanical agglutination of characters, neither a mosaic, but rather a new, original and independent phenomenon. In order to describe such a process, the Latin-rooted word trans-culturation provides a terminology that does not implies that a certain culture tends towarda another, but rather a transition between two cultures in which both are active and contributive as inputs, and both cooperative to the advent of a new civilization reality" (Malinowski, 1978, p. 4-5).

* Translated by Mateus Yuri Passos

IREFERENCES

Ackerman, D. (1993). Una historia natural de los sentidos. Barcelona: Anagrama.

Aguilera, O. (1992). La literatura en el periodismo y otros estudios en torno a la libertad y el mensaje informativo. Madrid: Paraninfo.

Balle, F. (1991). Comunicación y Sociedad: Evolución y análisis comparativo de los medios. Bogotá: Tercer Mundo Editores. 
Borrat, H. (1989). El periódico, actor político. Barcelona: Gustavo Gili.

Chillón, A. (1999). Literatura y periodismo. Una tradición de relaciones promiscuas. Barcelona: Universidad Autónoma de Barcelona.

Chillón, A. (2014). La palabra facticia. Literatura, periodismo y comunicación. Barcelona: Universidad Autónoma de Barcelona.

Gargurevich, J. (1982). Géneros Periodísticos. Quito: Ciespal

Grijelmo, A. (2001). El estilo del periodista. Madrid: Santillana.

Gutiérrez, H. (2014, Sep.). La historia de la prensa. México: La Jornada semanal, September 21 , n. 1020. Retrieved from http://www.jornada. unam.mx/2014/09/21/sem-bazar.html

Gutiérrez, P. J. (1984). Periodismo de opinión. Madrid: Paraninfo.

Hernando C. L. (2000). El discurso periodístico. Madrid: Editorial Verbum.

Jung, C. G. (1986). O pensamento vivo de Jung. São Paulo: Martin Claret.

Malinowski, B. (1978). Introducción. En Ortiz. F. Contrapunteo cubano del tabaco y el azúcar. Caracas: Biblioteca Ayacucho.

Martín V. G. (1973). Géneros periodísticos. Madrid: Paraninfo.

Martínez A. J. (1983). Curso general de redacción periodística. Barcelona: Mitre.

Martínez V. F. (1996). Herramientas periodísticas. Salamanca: Librería Cervantes.

Matute, A. (1997). Crónica: historia o literatura. Historia Mexicana, 46(4), pp. 711-22. Retrieved from https://historiamexicana.colmex. $\mathrm{mx} /$ index.php/RHM/article/view/2455

Medina, C. (1995). Entrevista o diálogo possível. São Paulo: Editora Ática.

Mèlich, J. (2015). La lectura como plegaria. Fragmentos filosóficos I. Barcelona: Fragmenta Editorial.

Melo, J. M. (2006). Teoria do jornalismo: identidades brasileiras. São Paulo: Paulos Editora.

Merleau- Ponty M. (1971). Fenomenologia da Percepção. Río de Janeiro: Freitas Bastos.

Mignolo, W. (1982). Cartas, crónicas y relaciones del descubrimiento y la conquista. En: L. Madrigal (Ed.), Introdução a Historia de la literatura hispanoamericana. I. Época colonial (pp. 57-102). Madrid: Cátedra. 
Monsiváis, C. (2005, Dez.). De la hora del ángelus a la del zapping. La crónica en América Latina. Letras Libres, on-line. Retrieved from https:// www.letraslibres.com/mexico/la-hora-del-angelus-la-del-zapping

Monsiváis, C. (2010). A ustedes les consta. Antología de la crónica en México. México D.F: ediciones Era (edición corregida y ampliada).

Morin, E. (1977). La Methode: Tomo 1. Paris: Les éditions du Seuil.

Morin, E. (1995). Sociología. Madrid: Tecnos.

Osorio V. R. (2017). El reportaje como metodología del periodismo. Una polifonía de saberes. Medellín: Editorial Universidad de Antioquia.

Rotker, S. (1992). Fundación de una escritura: Las crónicas de José Martí. La Habana: Ediciones Casa de las Américas.

Vilamor, J. R. (2000). Redacción periodística para la generación digital. Madrid: Universitas.

White, H. (1992) Metahistoria: la imaginación historica en la Europa del Siglo XIX. México: Fondo de Cultura Económica

Yanes M. R. (2006). La crónica, un género del periodismo literario equidistante entre la información y la interpretación. Espéculo: Revista de estudios literarios, 32, on-line. Retrieved from https:// pendientedemigracion.ucm.es/info/especulo/numero32/cronica.html

RAÚL HERNANDO OSORIO VARGAS has a master degree (1999) and PhD (2003) in Communication Sciences, from the School of Communications and Arts of the University of São Paulo. He is a full professor at the University of Antioquia, in the School of Communications and member of the Literary Studies Group, GEL. Email: osoriova@gmail.com 